Tropical Journal of Pharmaceutical Research October 2017; 16 (10): 2477-2486

ISSN: $1596-5996$ (print); 1596-9827 (electronic)

(C) Pharmacotherapy Group, Faculty of Pharmacy, University of Benin, Benin City, 300001 Nigeria.

All rights reserved.

Available online at http://www.tjpr.org

Original Research Article

http://dx.doi.org/10.4314/tjpr.v16i10.23

\title{
Construction and evaluation of a novel triple cell epitope- based polypeptide vaccine against cow mastitis induced by Staphylococcus aureus, Escherichia coli and Streptococcus
}

\author{
Xiang Liu*, Chunlin Chen, Chen Chen, Gregory Marslin, Rui Ding, Sanqiao Wu \\ Chinese-German Joint Institute for Natural Product Research, College of Biological Science and Engineering, Shaanxi \\ University of Technology; Shaanxi Engineering Research Center of Tall Gastrodia Tuber and Medical Dogwood, Hanzhong \\ 723001, China \\ *For correspondence: Email: liuxiang888525@163.com; Tel/Fax: +86-0916-2641661
}

Revised accepted: 19 September 2017

\begin{abstract}
Purpose: To construct a novel triple cell epitope-based polypeptide vaccine against cow mastitis induced by Staphylococcus aureus, Escherichia coli and Streptococcus and to reduce the use of antibiotics.

Methods: Based on bioinformatics approach, a novel triple epitope-based polypeptide (CM-TEP) was designed and subjected to Ni-NTA flow resin purification. Purified CM-TEP was immunized into mice to prepare a polyclonal antibody. Pull-down assays and enzyme-linked immunosorbent assay (ELISA) were used to detect the interaction between CM-TEP antibodies and S. aureus, E. coli and Streptococcus. Active immunity mice and challenge of bacterial pathogens were used to detect immune protection of CM-TEP. Additionally, the optimal expressing conditions of CM-TEP strain were analyzed using orthogonal test design.

Results: A novel cow mastitis triple cell epitope-based polypeptide (CM-TEP) with a MW of $36 \mathrm{kDa}$ was designed, purified and used to immunize mice to prepare a polyclonal antibody. Pull-down assays and ELISA data showed that CM-TEP antibodies directly interacted with S. aureus, E. coli and Streptococcus. CM-TEP displayed a significant immune protective effect against infection by $S$. aureus $(50 \%, p<0.05)$ and $E$. coli $(54.54 \%, p<0.05)$ and provided some immune protective effect $(30.78 \%$, $p>0.05)$ against Streptococcus. The optimum expressing conditions of CM-TEP were as follows: IPTG concentration of $0.3 \mathrm{mmol} / \mathrm{L}$, strain $\mathrm{OD} 600$ value of 1 , inducing temperature of $37^{\circ} \mathrm{C}$, and inducing time of $8 \mathrm{~h}$.

Conclusion: The findings suggest that epitope-based vaccine of CM-TEP may be a useful strategy for treating cow mastitis induced by S. aureus, E. coli and Streptococcus.
\end{abstract}

Keywords: Cow mastitis, Epitope vaccine, Immunogenicity, Immune protective

Tropical Journal of Pharmaceutical Research is indexed by Science Citation Index (SciSearch), Scopus, International Pharmaceutical Abstract, Chemical Abstracts, Embase, Index Copernicus, EBSCO, African Index Medicus, JournalSeek, Journal Citation Reports/Science Edition, Directory of Open Access Journals (DOAJ), African Journal Online, Bioline International, Open-J-Gate and Pharmacy Abstracts

\section{INTRODUCTION}

Cow mastitis is the most frequent and costly disease affecting dairy products worldwide [1], and its main pathogens include Staphylococcus aureus (S. aureus), Streptococcus and
Escherichia coli (E. coli). At present, using antibiotics to treat mastitis can cause drug residues to be present in dairy products and can lead to the development of antibiotic resistance [2]. However, a single-dose vaccine that is effective against all three major bacterial 
pathogens of cow mastitis has not been developed.

Epitope vaccines are a new type of vaccines that have been developed in recent years. Compared with traditional vaccines, epitope vaccines can easily be recognized by major histocompatibility complex (MHC) molecules with different genetic backgrounds, and they have been studied for use against viruses and bacteria and in cancer immunotherapy $[3,4]$. To date, research has shown that many proteins are good candidates for mastitis vaccine, including clumping factor $A$ (ClfA) and elastin binding protein (EbpS) of $S$. aureus [5,6], outer membrane protein $\mathrm{C}(\mathrm{OmpC})$ and outer membrane protein $A(O m p A)$ of $E$. coli $[7,8]$, and surface immunogenic protein (SIP) and phosphoglycerate kinase (PGK) of Streptococcus $[9,10]$. This study sought to construct and evaluate a novel triple-cell epitope-based vaccine for cow mastitis (CM-TEP), using these six proteins.

\section{EXPERIMENTAL}

\section{Chemicals and reagents}

(HRP)-conjugated secondary antibodies, PBS and TMB were purchased from Sigma. Freund's Complete Adjuvant and Freund's Incomplete Adjuvant was purchased from Shanghai Sangon Biotech. Corp (Shanghai, China). CM-TEP nucleic acid sequences were synthesized and cloned in E. coli BL21 by the Shanghai Xuguan Biotech Development Corp (Shanghai, China).

\section{Animals}

SPF Kunming mice (6 weeks old) were purchased from Xian Jiaotong University College of Medicine (Xian, China). All the animal experimental protocols were performed in accordance with the guidelines prescribed in Guide for the Care and Use of Laboratory Animals [11] and were approved by the Animal Ethical Committee (ref. no. 20150208), Shaanxi University of Technology, China.

\section{Protein materials}

According to the amino acid sequence deposited in NCBI GenBank, the accession numbers of ClfA and EbpS proteins of $S$. aureus are EFM05894.1 and EFM06457.1, respectively; OmpC and OmpA of E. coli are AIL15476.1 and ELV73478.1, respectively; and SIP and PGK of Streptococcus are AEL21614.1 and AKU04271.1, respectively.

\section{Cell epitope analysis}

ABCpred (http://www.imtech.res.in/raghava/abcp red/ABC_submission.html) and the BepiPred 1.0b (http://www.cbs.dtu.dk/services/BepiPred/) [12] software programs were used to predict the $B$ cell epitopes of the proteins. nHLAPred (http://www.imtech.res.in/raghava/nhlapred/comp .html) [3] and ProPred (http://www.imtech.res.in/ raghava/propred/) [4] were used to predict the cell epitope peptide segments of helper $\mathrm{T}$ cells (Th) and cytotoxic $\mathrm{T}$ lymphocytes (CTL), respectively. Four glycine residues (GGGG) were inserted into each epitope, and DNASTAR software was used to optimize the arrangement of the cell epitopes. The optimal antigenic combination was chosen as the final triple epitope polypeptide vaccine for cow mastitis (CM-TEP). The corresponding nucleic acid sequences were obtained by translation of the CM-TEP sequence.

Prokaryotic expression, purification and antiserum preparation of CM-TEP

CM-TEP nucleic acid sequences were synthesized and cloned in E. coli BL21 by the Shanghai Xuguan Biotech Development Corp., China. Prokaryotic expression and purification were performed as described previously [13]. Five-week-old Kunming mice were administered purified protein (100 $\mathrm{\mu g}$ per mouse) emulsified with Freund's Complete Adjuvant (Shanghai Sangon Biotech. Corp., China), then given two injections of Freund's Incomplete Adjuvant (Shanghai Sangon Biotech. Corp., China) at intervals of 14 days. Serum samples were collected from the mice and stored at $-80^{\circ} \mathrm{C}$.

Pull-down assays and ELISA to detect the interaction between CM-TEP antiserum and bacteria

The bacterial pull-down assay was implemented as described previously [13]. Briefly, Bacterial cultures at $\mathrm{OD}_{600} 1.0$ were harvested by centrifugation, and the bacteria were washed with physiological saline $(0.85 \% \mathrm{NaCl})$. After the addition of $1 \%$ oxymethylene (W/V) for $90 \mathrm{~min}$ at $80{ }^{\circ} \mathrm{C}$, the bacterial pellet was resuspended in physiological saline, and the final concentration was adjusted to $0.2 \mathrm{OD}$ at $600 \mathrm{~nm}$. One milliliter of bacterial suspension containing approximately $10^{8} \mathrm{CFU} / \mathrm{mL}$ bacterial cells was transferred into each 1.5-mL tube. After centrifugation, $100 \mu \mathrm{L}$ of CM-TEP antiserum at various dilutions was added to the tubes and incubated for $1 \mathrm{~h}$ at 37 ${ }^{\circ} \mathrm{C}$. Additionally, $2 \mu \mathrm{g} / \mu \mathrm{L}$ BSA was used as the negative control. After being washed, the bacteria were combined with rabbit anti-mouse 
secondary antibodies at a dilution of 1:3000 for 1 $\mathrm{h}$ at $37^{\circ} \mathrm{C}$ and washed again with PBS. After suspension of the bacteria in $20 \mu \mathrm{L}$ of PBS, the samples were transferred to enzyme-labeled plates, and coloration liquid $\left(50 \mu \mathrm{L}\right.$ of $\mathrm{H}_{2} \mathrm{O}_{2}$ and $50 \mu \mathrm{L}$ of TMB) was added to each well. Plates were maintained in the dark at $37^{\circ} \mathrm{C}$ to allow the color reaction to develop. After $10 \mathrm{~min}, 50 \mu \mathrm{L}$ of stop solution $\left(2 \mathrm{M} \mathrm{H}_{2} \mathrm{SO}_{4}\right)$ was added to each well, and the absorbance was read at $450 \mathrm{~nm}$ using a microplate reader (Bio-Rad, USA).

\section{Active immunity and challenge}

Mice were randomly divided into groups, and purified CM-TEP protein was intraperitoneally injected two times at an interval of 10 days, to deliver the primary and booster doses. Freund's Complete Adjuvant and Freund's Incomplete Adjuvant emulsified with CM-TEP protein (100 $\mu \mathrm{g}$ per mouse) was utilized in the primary and booster immunizations, respectively. The control groups were immunized with Freund's adjuvant. Immunized mice were intraperitoneally challenged with $S$. aureus, E. coli and Streptococcus at one week after the second immunization. Mice were observed for 15 days to measure their relative percentage survival (RPS). Protection rates were expressed as in Eq 1.

$\mathrm{RPS}=\left[1-\frac{\mathrm{Nt}}{\mathrm{Nc}}\right] 100$

where $N t$ represents the vaccinated mortality in test group (triple epitope polypeptide vaccine of cow mastitis, CM-TEP), and Nc the nonvaccinated mortality for control group. Statistical significance between groups was tested using SPSS software.

\section{Optimization of expression condition of $\mathrm{CM}$ - TEP}

In order to optimize the expression conditions of CM-TEP protein, we have chosen orthogonal experiment design $\mathrm{L}_{9}\left(3^{4}\right)$ [14], which is a four factors and three-level orthogonal design, and the factors are as follows: strain $O D_{600}$ value $(\mathrm{A})$, IPTG concentration (B), inducing time (C), and inducing temperature (D). In brief, according to $\mathrm{L}_{9}\left(3^{4}\right)$ matrix mode, once the concentration of bacterial culture was reached, different concentrations of IPTG was added to the culture to induce protein production with appropriate temperature. Bacterial cells were harvested at the corresponding time based $\mathrm{L}_{9}\left(3^{4}\right)$ matrix, heated for $5 \mathrm{~min}$ in boiling water and the proteins were electrophoresed by SDS-PAGE. The protein bands were visualized by staining with G-250. The optical density of CM-TEP protein bands was analyzed by Phoretix 1D software. Statistical analysis of the dataset was conducted using Statistical Package for the Social Science (SPSS) software. The experiment was repeated three times.

\section{RESULTS}

\section{In silico prediction of B cell epitopes}

B cell epitopes of proteins were predicted by using the BepiPred 1.0b (Table 1) and ABCpred (Table 2) programs. On the basis of the common epitope sequence predicted by the two programs, the B cell epitope segment of $S$. aureus ClfA protein was at residues $114-129$ and $326-330$, and that of the Ebps protein was at residues $87-102$ and $132-147$. The $B$ cell epitope segment of $E$. coli OmpA protein was at residues $44-50$ and $126-135$, and that of the OmpC protein was at residues $19-31$ and $129-$ 144. The B cell epitope segment of Streptococcus SIP protein was at residues 224 238 and $346-358$, and that of the PGK protein was at residues $64-79$ and $324-329$.

\section{In silico prediction of CTL cell epitopes}

On the basis of the nHLAPred method, the CTL cell epitope segment of Ebps and ClfA protein was at residues 318 - 326 and 895 - 902, respectively; the OmpA and OmpC of $E$. coli were at residues $237-245$ and $295-303$, respectively; and the Streptococcus PGK protein was at resides $73-81$, but the SIP protein did not display a CTL cell epitope (Table 3).

Table 1: Identification of B cell epitopes for proteins by using the BepiPred 1.0b method

\begin{tabular}{|c|c|}
\hline $\begin{array}{l}\text { Protein } \\
\text { name }\end{array}$ & Peptide segment position \\
\hline Ebps & $\begin{array}{l}6-60,69-121,127-318,346-446,457-467, \\
473-481\end{array}$ \\
\hline ClfA & $\begin{array}{l}34-203,205-211,223-234,242-254,264- \\
272,288-299,323-330,338-347,355-362 \\
385-394,399-407,415-428,464-484\end{array}$ \\
\hline OmpA & $\begin{array}{l}19-30,44-59,61-67,83-95,126-145,165- \\
181\end{array}$ \\
\hline OmpC & $\begin{array}{l}19-31,46-55,64-93,129-144,170-212, \\
221-252,264-270,277-283,315-321\end{array}$ \\
\hline SIP & $\begin{array}{l}23-35,45-56,97-104,107-125,144-154 \\
160-169,179-216,218-238,242-249,253 \\
288,290-325,334-342,346-358,375-384 \\
402-423\end{array}$ \\
\hline PGK & $\begin{array}{l}64-76,120-136,188-194,269-277,280- \\
290,324-334,344-359\end{array}$ \\
\hline
\end{tabular}

Trop J Pharm Res, October 2017; 16(10): 2479 
Table 2: Identified B cell epitopes for proteins based on ABCpred method

\begin{tabular}{|c|c|}
\hline $\begin{array}{l}\text { Protein } \\
\text { name }\end{array}$ & Peptide segment position \\
\hline Ebps & $87-102, \quad 132-147$ \\
\hline ClfA & $\begin{array}{l}114-129, \quad 326-341, \quad 395-410, \quad 533- \\
548,848-863\end{array}$ \\
\hline OmpA & $\begin{array}{l}35-50,87-102,120-135,153-168 \\
214-229, \quad 298-313\end{array}$ \\
\hline OmpC & $16-31, \quad 129-144, \quad 283-298$ \\
\hline SIP & $106-121, \quad 224-239, \quad 346-361$ \\
\hline PGK & $61-76, \quad 135-150,221-236, \quad 314-329$ \\
\hline
\end{tabular}

\section{In silico prediction of Th cell epitopes}

Using the ProPred method, we predicted the Th epitopes of the six proteins (Table 4). Th cell epitopes segments of $S$. aureus Ebps and ClfA protein were at residues $479-487$ and 201 209, respectively; the OmpA and OmpC protein of $E$. coli were at residues $284-292$ and $6-12$, respectively; and the PGK and SIP protein of
Streptococcus were at residues $317-325$ and $240-248$, respectively.

\section{Reorganization of series epitopes}

Different possible arrangement and combinations of epitopes were optimized by using DNAStar software (Figure 1), and the final amino acid sequence was as follows:

KDDVKGGGGIRNGQQIVIGGGGVVNQAVNTS GGGGGMAKVLLPLGGGGPEPIEDNDKHDTIKN AGGGGAGTIDDRQVESSHSTEGGGGTGEATT TTTNQANTPAGGGGLLASIGSLGGGGANAAEV YNKDGNKGGGGALDQLYSQLGGGGDTKSNVY GKNGGGGLSLLVPAGGGGFINNNGPGGGGPE FGGDTYGSDNFMQQGGGGGLRPSVAYLGGG GYLISKGIPAGGGGGVFENPGGGGVRTVAAPR VGGGGTYRAGDPGDHGKGGGGGSLAPVAAD LGGGGKEEADKEGKSLAPVAAGGGGVVWNG PMGVGGGGASVAAETPAPVAKVA.

Table 3: Identified CTL epitopes for proteins

\begin{tabular}{|c|c|c|c|}
\hline Protein name & Rank & Type & Peptide segment position \\
\hline \multirow[t]{5}{*}{ EbpS } & 1 & HLA-A2 & 119-127, 318-330, 337-345 \\
\hline & 2 & HLA-A*0201 & $318-330$ \\
\hline & 3 & HLA-A*0202 & $318-330$ \\
\hline & 4 & HLA-A*0203 & $318-326$ \\
\hline & 5 & HLA-A*0205 & $269-277, \quad 318-331, \quad 332-340$ \\
\hline \multirow[t]{5}{*}{ ClfA } & 1 & HLA-A2 & $504-512, \quad 894-902$ \\
\hline & 2 & HLA-A*0201 & $895-903$ \\
\hline & 3 & HLA-A*0202 & $895-903$ \\
\hline & 4 & HLA-A*0203 & $121-129, \quad 290-296, \quad 297-305, \quad 425-433, \quad 895-903$ \\
\hline & 5 & HLA-A*0205 & $220-228, \quad 353-361, \quad 406-141,538-546,891-899$ \\
\hline \multirow[t]{5}{*}{ OmpA } & 1 & HLA-A2 & $117-125, \quad 181-189, \quad 237-245$ \\
\hline & 2 & HLA-A*0201 & $237-248$ \\
\hline & 3 & HLA-A*0202 & $237-245$ \\
\hline & 4 & HLA-A*0203 & $11-19, \quad 100-108$ \\
\hline & 5 & HLA-A*0205 & $\begin{array}{l}11-18, \quad 19-27, \quad 55-63,92-99, \quad 100-108,110-116, \quad 117-125, \\
152-160,209-217,222-230,237-245\end{array}$ \\
\hline \multirow[t]{5}{*}{ OmpC } & 1 & HLA-A2 & $7-15, \quad 73-81, \quad 113-121, \quad 258-266, \quad 295-303$ \\
\hline & 2 & HLA-A*0201 & $7-15,295-303$ \\
\hline & 3 & HLA-A*0202 & $7-15, \quad 197-205,295-303$ \\
\hline & 4 & HLA-A*0203 & $258-266, \quad 288-296$ \\
\hline & 5 & HLA-A*0205 & $33-41,97-105,295-303,322-330,353-361$ \\
\hline \multirow[t]{5}{*}{ SIP } & 1 & HLA-A2 & ---- \\
\hline & 2 & HLA-A*0201 & $12-20, \quad 67-75$ \\
\hline & 3 & HLA-A*0202 & $226-234$ \\
\hline & 4 & HLA-A*0203 & $2-10, \quad 147-155,254-262$ \\
\hline & 5 & HLA-A*0205 & 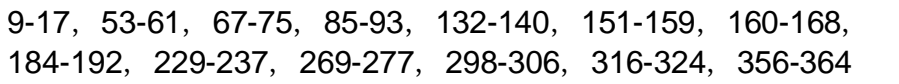 \\
\hline \multirow[t]{5}{*}{ PGK } & 1 & HLA-A2 & $55-63$ \\
\hline & 2 & HLA-A*0201 & $16-24,73-81,99-105,106-114,134-142$ \\
\hline & 3 & HLA-A*0202 & $16-24, \quad 55-63,73-81,99-107, \quad 161-169,260-268,310-318$ \\
\hline & 4 & HLA-A*0203 & $73-81$ \\
\hline & 5 & HLA-A*0205 & $\begin{array}{l}33-39, \quad 40-48,73-85,134-142,151-159,310-318,334-342 \\
, \quad 344-352, \quad 387-395\end{array}$ \\
\hline
\end{tabular}


Table 4: Identified Th epitopes for proteins

\begin{tabular}{|c|c|c|c|}
\hline Protein name & Rank & Type & Peptide segment position \\
\hline \multirow[t]{3}{*}{ EbpS } & 1 & $\begin{array}{l}\text { DRB1- } \\
0101\end{array}$ & $324-329,330-335,336-344,450-458,468-476,479-487$ \\
\hline & 2 & $\begin{array}{l}\text { DRB1- } \\
0102\end{array}$ & $324-329, \quad 336-344,468-476, \quad 479-487$ \\
\hline & 3 & $\begin{array}{l}\text { DRB1- } \\
0301\end{array}$ & $331-339,449-157,479-487$ \\
\hline \multirow[t]{3}{*}{ ClfA } & 1 & $\begin{array}{c}\text { DRB1- } \\
0101\end{array}$ & $\begin{array}{l}\begin{array}{l}23-28, \\
901\end{array} \\
99-37, \quad 141-149,201-209,261-269,275-283,372-379,893-\end{array}$ \\
\hline & 2 & $\begin{array}{c}\text { DRB1- } \\
0102\end{array}$ & $29-37, \quad 141-149, \quad 201-209,257-265,275-283,350-358,896-904$ \\
\hline & 3 & $\begin{array}{l}\text { DRB1- } \\
0301\end{array}$ & $21-29, \quad 201-209,221-229,241-249, \quad 303-311,376-384$ \\
\hline \multirow[t]{3}{*}{ OmpA } & 1 & $\begin{array}{l}\text { DRB1- } \\
0101\end{array}$ & $44-52, \quad 189-197, \quad 284-292$ \\
\hline & 2 & $\begin{array}{c}\text { DRB1- } \\
0102\end{array}$ & $6-13,284-292$ \\
\hline & 3 & $\begin{array}{l}\text { DRB1- } \\
0301\end{array}$ & $\begin{array}{l}\text { 74-82, 98-106, 123-131, } 148-155,185-193,217-225,256-264,290- \\
298,324-331\end{array}$ \\
\hline \multirow[t]{3}{*}{ OmpC } & 1 & $\begin{array}{c}\text { DRB1- } \\
0101\end{array}$ & $\begin{array}{l}6-12, \quad 14-22, \quad 111-119, \quad 141-149,152-157,158-166,170-178,216- \\
224, \quad 302-310, \quad 335-343, \quad 355-363\end{array}$ \\
\hline & 2 & $\begin{array}{c}\text { DRB1- } \\
0102\end{array}$ & $6-12, \quad 14-22, \quad 158-166,216-224, \quad 296-304, \quad 355-363$ \\
\hline & 3 & $\begin{array}{l}\text { DRB1- } \\
0301\end{array}$ & $5-17,43-51, \quad 57-65,101-109,117-124,250-258,366-375$ \\
\hline \multirow[t]{3}{*}{ SIP } & 1 & $\begin{array}{c}\text { DRB1- } \\
0101\end{array}$ & $1-9, \quad 17-25,84-92, \quad 240-248,363-371$ \\
\hline & 2 & $\begin{array}{c}\text { DRB1- } \\
0102\end{array}$ & $1-9, \quad 17-25,84-92, \quad 107-115,240-248$ \\
\hline & 3 & $\begin{array}{c}\text { DRB1- } \\
0301\end{array}$ & $\begin{array}{l}\text { 45-53, 55-63, 68-76, 95-102, 132-140, 155-163, 240-248, 359-367, } \\
391-399\end{array}$ \\
\hline \multirow[t]{3}{*}{ PGK } & 1 & $\begin{array}{l}\text { DRB1- } \\
0101\end{array}$ & $46-54, \quad 146-154, \quad 197-205,232-240, \quad 317-325,342-350,381-389$ \\
\hline & 2 & $\begin{array}{c}\text { DRB1- } \\
0102\end{array}$ & $146-154, \quad 197-205, \quad 232-240, \quad 317-325, \quad 342-350, \quad 381-389$ \\
\hline & 3 & $\begin{array}{l}\text { DRB1- } \\
0301\end{array}$ & $18-26, \quad 31-39, \quad 55-63,89-97, \quad 222-230, \quad 252-260, \quad 295-303, \quad 317-325$ \\
\hline
\end{tabular}

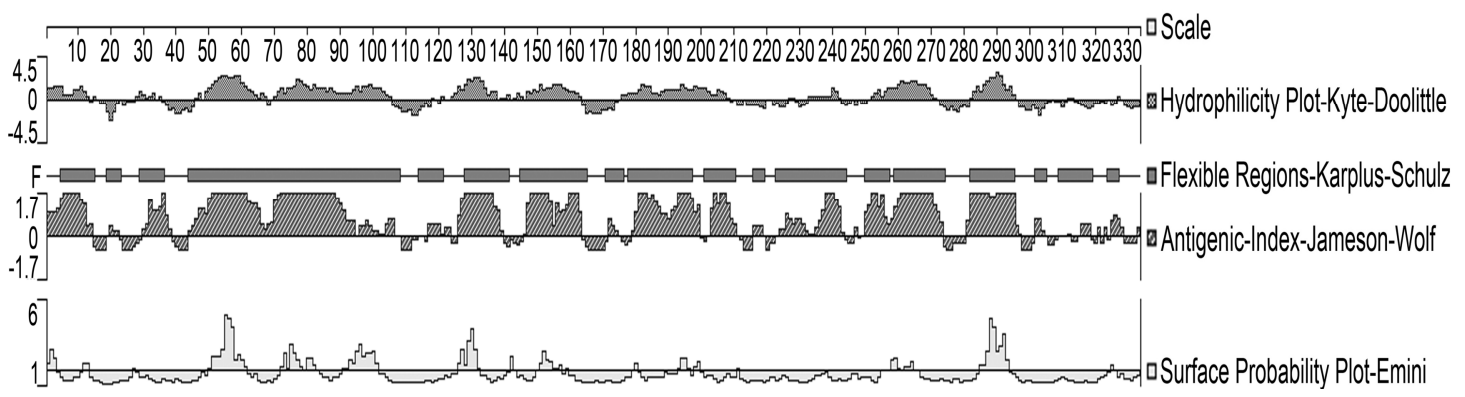

Figure 1: Antigenic index of the CM-TEP. The predicted epitopes were connected by GGGG flexible regions, thus making them independent of each other

Prokaryotic expression, purification and immunogenicity analysis of CM-TEP

Heterologous expression of CM-TEP in E. coli and induction with IPTG resulted in the production of a protein of approximately $56 \mathrm{kDa}$ in size, which corresponded to a fusion protein of $20.4 \mathrm{kDa}$ and CM-TEP of $36 \mathrm{kDa}$ (Figure 2). This was the expected size of the recombinant protein. A reasonable quantity of CM-TEP was purified by Ni-NTA super flow resin (Figure 2 and Figure 3). Purified CM-TEP was used to immunize mice to prepare a polyclonal antibody. Pull-down and ELISA results showed that the $O D$ $450 \mathrm{~nm}$ value decreased as the CM-TEP antiserum dilution increased and was near to zero in the control serum (Figure 3). These data indicated a direct interaction between CM-TEP antiserum and $S$. aureus, E. coli and Streptococcus. 


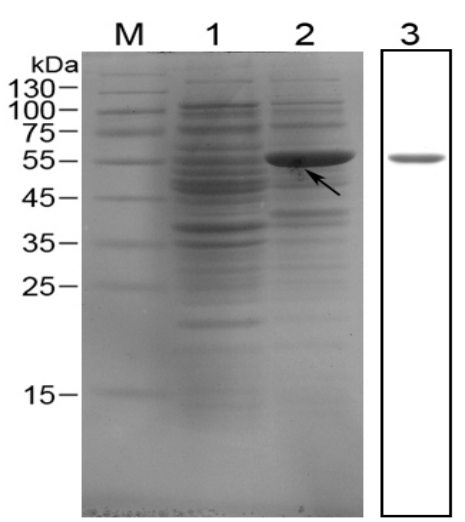

Figure 2: Expression and purification of CM-TEP. M, protein marker. 1, non-induced strain. 2, IPTG-induced strain. 3, purified CM-TEP. Heterologous expression of CM-TEP in E. coli and induction with IPTG resulted in the production of a protein of approximately $56 \mathrm{kDa}$ in size, including a fusion protein of $20.4 \mathrm{kDa}$ and $\mathrm{CM}$ TEP of $36 \mathrm{kDa}$. This was the expected size of the recombinant protein. A reasonable quantity of $\mathrm{CM}$ TEP was purified using Ni-NTA super flow resin and produced only one band

\section{CM-TEP immune protective}

An active immunization approach was used to investigate the ability of CM-TEP to protect mice against infection. After infection with $S$. aureus, E. coli and Streptococcus, the mice showed severe symptoms. Many of the mice died, but those that survived were able to gradually resume activities after 4 days. Compared with the control group of Freund's immunized adjuvant, the CM-TEP group displayed a significant immune protective effect against infection by $S$. aureus $(50 \%, p<0.05)$ and $E$. coli $(54.54 \%, P<0.05)$ and provided some immune protection against Streptococcus (30.78 $\%, p>0.05$ ) (Table 5).

\section{Optimization of expression condition of CM- TEP expression strain}

Based on orthogonal design and SDS-PAGE electrophoresis, the expression of CM-TEP was shown in Figure 4. Optical density value of $\mathrm{CM}$ TEP bands was analyzed by Phoretix 1D software (Table 5). By comparing the K1, K2 and K3 in Table 5, the optimal expression condition of CM-TEP was A3, B2, C2 and D3, which meant strain $O D_{600}$ value of 1 , IPTG concentration of $0.3 \mathrm{mmol} / \mathrm{L}$, inducing time of $8 \mathrm{~h}$ and inducing temperature of $37{ }^{\circ} \mathrm{C}$, respectively. Range analysis showed that the influence degree of each factors on the expression of CM-TEP was $\mathrm{C}>\mathrm{B}>\mathrm{D}>\mathrm{A}$ (Table 6). For CM-TEP expressing, notable statistical significance of factors were IPTG concentration, inducing time and inducing temperature (Table 7).
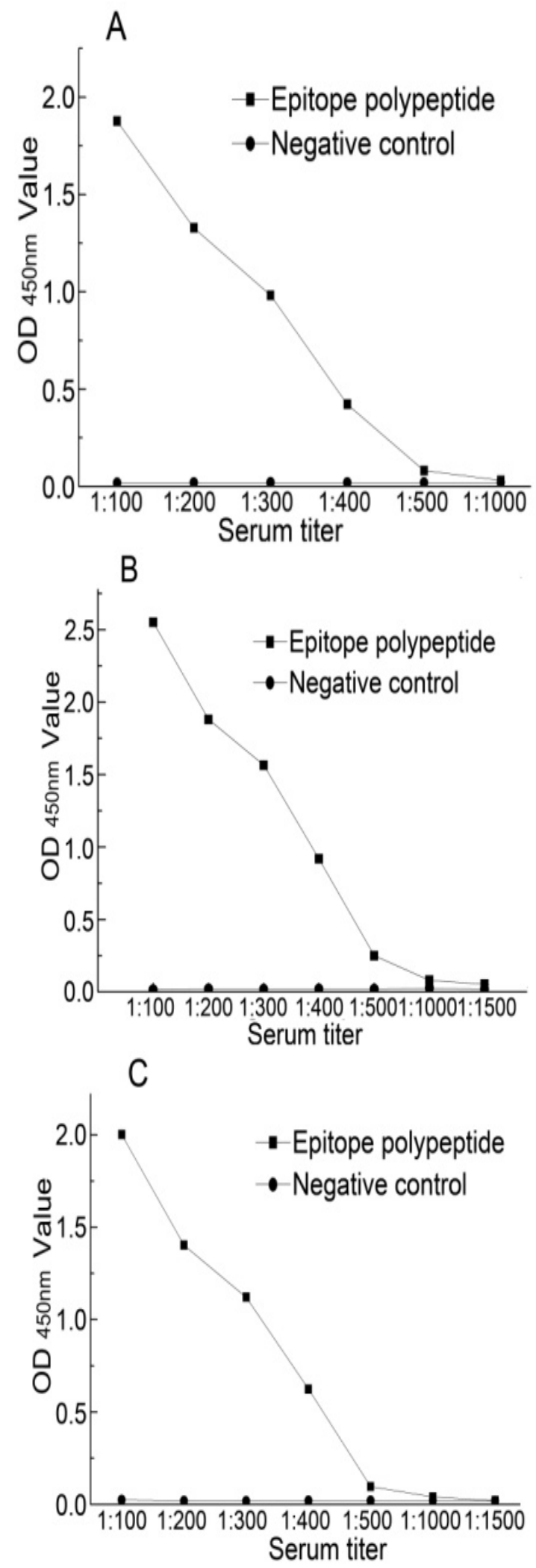

Figure 3: The interaction between CM-TEP antiserum and the three bacterial pathogens, as determined by ELISA. $A, B$ and $C$ were CM-TEP antiserum interaction with $S$. aureus, E. coli and Streptococcus, respectively. The $O D_{450}$ value decreased as the serum dilution increased and was almost zero in control serum 

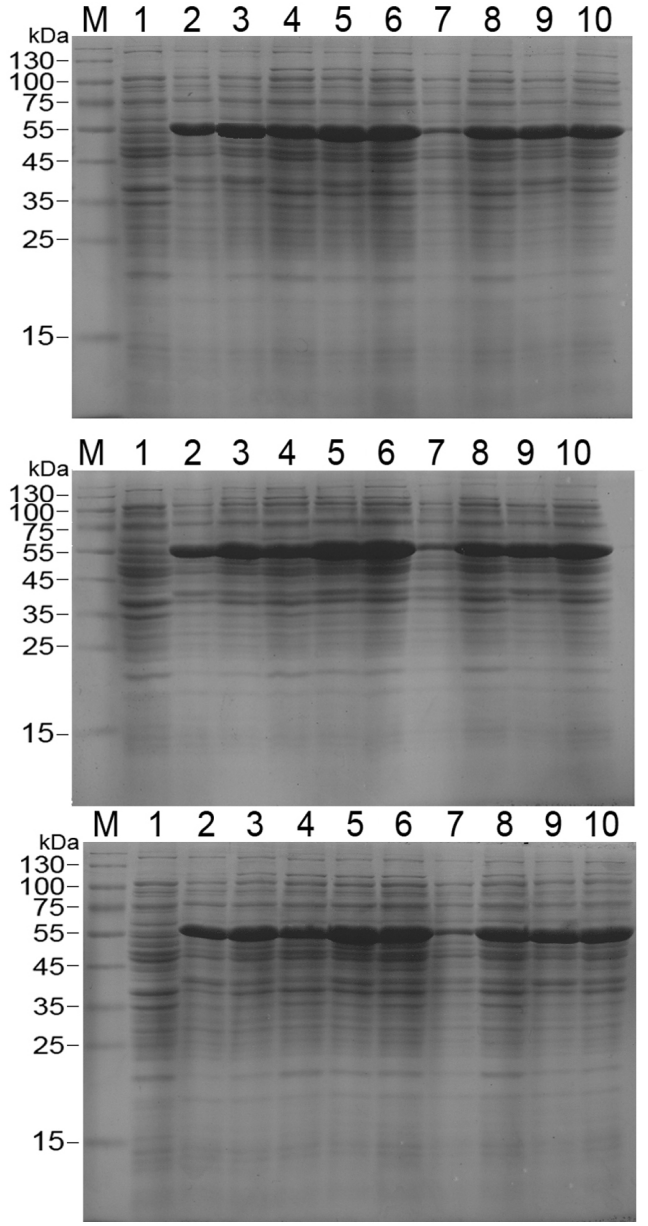

Figure 4: Inducing expressing of CM-TEP expression strain. M: Protein marker. 1, non-induced strain. $2-4$ : strain $O D_{600}$ value of 0.5 , IPTG concentration of 0.1 , 0.3 and $0.5 \mathrm{mmol} / \mathrm{L}$, inducing time was 3,8 and $12 \mathrm{~h}$, and inducing temperature: 28,32 and $37^{\circ} \mathrm{C}$. $5-7$ : strain $O D_{600}$ value of 0.8 , IPTG concentration of 0.1 , 0.3 and $0.5 \mathrm{mmol} / \mathrm{L}$, inducing time: 8,12 and $3 \mathrm{~h}$, and inducing temperature: 32,28 and $37^{\circ} \mathrm{C} .8-10$ : strain $O D_{600}$ value of 1 , IPTG concentration of $0.1,0.3$ and $0.5 \mathrm{mmol} / \mathrm{L}$, inducing time: 12,3 and $8 \mathrm{~h}$, and inducing temperature: 32,37 and $28{ }^{\circ} \mathrm{C}$

\section{DISCUSSION}

There are many methods available for predicting $B$ cell epitopes, including BepiPred, ABCpred and BPAP [15]. Through BepiPred and ABCpred, the $B$ cell epitopes were predicted for membraneassociated proteins of $C$. jejuni [12] and Gly $\mathrm{m}$ $\mathrm{Bd} 28 \mathrm{~K}$ of soybean allergens [16]. This study used a combination of the BepiPred and $A B C p r e d$ methods to improve the prediction accuracy of the B cell epitope for the six proteins.

CTL cell epitopes play an integral role in the adaptive immune response by recognizing peptides combine to major histocompatibility complex class I (MHC-I) molecules; the prediction methods include nHLAPred, IEDB,
SYFPEITHI and IMTECH [17]. The nHLAPred method has been used to predict CTL cell epitopes for Leishmania major-related candidate antigens and HIV Gag protein [3]. We used the same method to identify a novel critical epitope, which may play a major role in activating $C D 8^{+} T$ cells [3], thereby increasing the development of immunogenicity.

The ProPred method was found to be efficient for the Th epitope prediction of bacteria [4] and viral proteins [18]. In this article, we used the ProPred method to obtain protein Th epitopes, which could be combined with MHC-II molecules to enhance the immune response.

The flexible portions are underlined. Epitope joints can be divided into flexible and rigid, and frequently used amino acid connection joints sequences are GGGG, AAY, KK and GGGGS [19]. DNAStar software can be used to recombine epitopes for optimal antigenicity [20]. We used the GGGG amino acid joint and used DNAStar software to optimize different epitopes to obtain a polypeptide (CM-TEP) with optimal antigenicity.

The cow mastitis researchers have found that recombinant epitope (Sip-ClfA) antiserum capacities for opsonizing, adhesion and phagocytosis are significantly greater than those of the killed bacteria after immunization, and that these recombinant epitopes also exhibit good immunogenicity [21]. This study indicated a direct interaction between CM-TEP antiserum and $S$. aureus, E. coli and Streptococcus. Thus, CMTEP was expected to have good immunogenicity. Additionally, several studies have found that immunization with the $B$ cell epitope (Sip-ClfA) provides better protection against both $S$. agalactiae and $S$. aureus challenges [21]. In this study, CM-TEP immunization developed an immune protection against all three major bacterial pathogens of cow mastitis. Thus, CM-TEP is expected to be an approach to the development of a vaccine against cow mastitis.

In order to apply to industrial production, the optimum expression conditions were studied to obtain abundant and high quality of CM-TEP, which were strain $O D_{600}$ value of 1 , IPTG concentration of $0.3 \mathrm{mmol} / \mathrm{L}$, inducing time of $8 \mathrm{~h}$ and inducing temperature of $37{ }^{\circ} \mathrm{C}$, respectively. IPTG is toxic [22] and should be induced by low concentration in practical production, and the same to our research. In addition, the suitable induction time is favorable to the synthesis of protein [23], and the production cost can be 
Table 5: Active immune protection achieved by CM-TEP

\begin{tabular}{lccc}
\hline Immune & $\begin{array}{c}\text { S. aureus } \\
\text { ADR(\%)/RPS(\%)/Sig(P) }\end{array}$ & $\begin{array}{c}\text { E. coli } \\
\text { ADR(\%)/RPS(\%)/Sig( } \boldsymbol{P})\end{array}$ & $\begin{array}{c}\text { Streptococcus } \\
\text { ADR(\%)/RPS(\%)/Sig( } \boldsymbol{P})\end{array}$ \\
\hline $\begin{array}{l}\text { CM-TEP } \\
\text { Control }\end{array}$ & $40 / 50 / 0.025$ & $33.33 / 54.54 / 0.028$ & $60 / 30.78 / 0.099$ \\
(Freund's \\
adjuvant)
\end{tabular}

ADR, accumulating death rates. RPS (\%) = 1 - (\% vaccinated mortality $/ \%$ non-vaccinated mortality $) \times 100$. Sig., significance. ${ }^{*} p<0.05$ (compared with control). CM-TEP displayed a significant immune protective effect against the infection of $S$. aureus $(50 \%, p<0.05)$ and $E$. coli $(54.54 \%, p<0.05)$, and displayed some immune protection against Streptococcus $(30.78 \%, p>0.05)$

Table 6: Inducing expression condition of CM-TEP strain

\begin{tabular}{lccccc}
\hline Number & $\mathbf{A}$ & $\mathbf{B}(\mathbf{m m o l} / \mathbf{L})$ & $\mathbf{C}(\mathbf{h})$ & $\mathbf{D}\left({ }^{\circ} \mathrm{C}\right)$ & Optical density/SD $\left(\times \mathbf{1 0}^{5}\right)$ \\
\hline 1 (A1B1C1D1) & 0.5 & 0.1 & 3 & 28 & $1.552 \pm 0.026$ \\
2 (A1B2C2D2) & 0.5 & 0.3 & 8 & 32 & $2.325 \pm 0.144$ \\
3 (A1B3C3D3) & 0.5 & 0.5 & 12 & 37 & $2.102 \pm 0.184$ \\
4 (A2B1C2D3) & 0.8 & 0.1 & 8 & 37 & $2.777 \pm 0.283$ \\
5 (A2B2C3D1) & 0.8 & 0.3 & 12 & 28 & $2.840 \pm 0.082$ \\
6 (A2B3C1D2) & 0.8 & 0.5 & 3 & 32 & $0.601 \pm 0.173$ \\
7 (A3B1C3D2) & 1.0 & 0.1 & 12 & 32 & $2.218 \pm 0.194$ \\
8 (A3B2C1D3) & 1.0 & 0.3 & 3 & 37 & $2.052 \pm 0.100$ \\
9 (A3B3C2D1) & 1.0 & 0.5 & 8 & 28 & $2.338 \pm 0.271$ \\
K1 (Mean value 1) & 1.993 & 2.182 & 1.401 & 2.243 & \\
K2 (Mean value 2) & 2.073 & $\mathbf{2 . 4 0 6}$ & $\mathbf{2 . 4 8 0}$ & 1.715 & \\
K3 (Mean value 3) & $\mathbf{2 . 2 0 3}$ & 1.681 & 2.387 & $\mathbf{2 . 3 1 0}$ & \\
Range analysis & 0.210 & 0.725 & 1.079 & 0.595 & \\
\hline
\end{tabular}

The factor of $A, B, C$, and $D$ means strain $O D_{600}$ value, IPTG concentration, inducing time and inducing temperature, respectively. By comparing the data size of $K 1, K 2$ and $K 3$, the optimal expression condition of CMTEP was A3, B2, C2 and D3. Range analysis showed that the influence degree of each factors on the expression of $C M-T E P$ was $C>B>D>A$

Table 7: Variance results for CM-TEP expressing

\begin{tabular}{cccc}
\hline Factor & \multicolumn{3}{c}{ Optical density value analysis } \\
\cline { 2 - 4 } & Mean square & $\boldsymbol{F}$ value & $\boldsymbol{P}$ value \\
\hline A & 0.101 & 3.096 & 0.070 \\
B & 1.241 & 38.109 & 0.000 \\
C & 3.215 & 98.738 & 0.000 \\
D & 0.957 & 29.406 & 0.000 \\
\hline
\end{tabular}

The factor of $\mathrm{A}, \mathrm{B}, \mathrm{C}$, and $\mathrm{D}$ means strain $O D_{600}$ value, IPTG concentration, inducing time and inducing temperature, respectively. $P<0.05$ means the difference with control group is significant

saved compared with the blind setting time. Thus, appropriate induction time should be used.

\section{CONCLUSION}

A novel triple-cell epitope-based polypeptide (CM-TEP) has been designed, optimized expression. It displays a significant immune protective effect against the infection of $S$. aureus and $E$. coli while providing some immune protection against Streptococcus. Thus, a new member has been added to the group of triple epitope-based vaccines against cow mastitis.

\section{DECLARATIONS Acknowledgement}

This study was supported by Science and Technology Research Development Program of Shaanxi Province (no. 2016NY-088), the Highend Foreign Experts Recruitment Programme of State Administration of Foreign Experts Affairs (no. GDT20176100048), and the Shaanxi Provincial Science and Technology Coordinating Innovative Engineering Project (no. 2015KTTSSF01-03 and 2015HBGC-18).

\section{Conflict of Interest}

No conflict of interest associated with this work.

\section{Contribution of Authors}

The authors declare that this work was done by the authors named in this article and all liabilities pertaining to claims relating to the content of this article will be borne by them.

\section{Open Access}

This is an Open Access article that uses a funding model which does not charge readers or their 
institutions for access and distributed under the terms of the Creative Commons Attribution License (http://creativecommons.org/licenses/by/ 4.0) and the Budapest Open Access Initiative (http://www.budapestopenaccessinitiative.org/rea d), which permit unrestricted use, distribution, and reproduction in any medium, provided the original work is properly credited.

\section{REFERENCES}

1. Bürki S, Spergser J, Bodmer M, Pilo P. A dominant lineage of Mycoplasma bovis is associated with an increased number of severe mastitis cases in cattle. Vet Microbiol 2016; 196: 63-66.

2. Hauck CG, Chong PP, Miller MB, Jamieson K, Fine JP, Foster MC, Shea TC, van Duin D. Increasing rates of fluoroquinolone resistance in Escherichia coli isolated from the blood and urine of patients with hematologic malignancies and stem cell transplant recipients. Pathog Immun 2016; 1(2): 234-242.

3. Abidi SH, Shahid A, Lakhani LS, Khanani MR, Ojwang P, Okinda N, Shah R, Abbas F, Rowland-Jones S, Ali S. Population-specific evolution of HIV Gag epitopes in genetically diverged patients. Infect Genet Evol 2013; 16: 78-86.

4. Saraav I, Pandey $K$, Sharma $M$, Singh $S$, Dutta $P$, Bhardwaj A, Sharma S. Predicting promiscuous antigenic $T$ cell epitopes of Mycobacterium tuberculosis mymA operon proteins binding to MHC Class I and Class II molecules. Infect Genet Evol 2016; 44:182-189.

5. Scully IL, Timofeyeva $Y$, Keeney D, Matsuka $Y V$, Severina E, McNeil LK, Nanra J, Hu G, Liberator PA, Jansen KU, Anderson AS. Demonstration of the preclinical correlate of protection for Staphylococcus aureus clumping factor $A$ in a murine model of infection. Vaccine 2015; 33(41): 5452-5457.

6. Nakakido M, Aikawa C, Nakagawa I, Tsumoto K. The staphylococcal elastin- binding protein regulates zincdependent growth/biofilm formation. J Biochem 2014; 156(3): 155-162.

7. Kudva IT, Krastins B, Torres AG, Griffin RW, Sheng $H$, Sarracino DA, Hovde CJ, Calderwood SB, John M. The Escherichia coli 0157:H7 cattle immunoproteome includes outer membrane protein $A$ (OmpA), a modulator of adherence to bovine rectoanal junction squamous epithelial (RSE) cells. Proteomics 2015; 15(11): 1829-1842.

8. Liu C, Chen Z, Tan C, Liu W, Xu Z, Zhou R, Chen H. Immunogenic characterization of outer membrane porins $\mathrm{OmpC}$ and $\mathrm{OmpF}$ of porcine extraintestinal pathogenic Escherichia coli. FEMS Microbiol Lett 2012; 337(2): 104-111.

9. Huang $L Y$, Wang $K Y$, Xiao $D$, Chen $D F$, Geng $Y$, Wang J, He $Y$, Wang EL, Huang JL, Xiao GY. Safety and immunogenicity of an oral DNA vaccine encoding Sip of Streptococcus agalactiae from Nile tilapia Oreochromis niloticus delivered by live attenuated Salmonella typhimurium. Fish Shellfish Immunol 2014; 38(1): 34-41.

10. Wang $Y T$, Huang $H Y$, Tsai MA, Wang $P C$, Jiang $B H$, Chen SC. Phosphoglycerate kinase enhanced immunity of the whole cell of Streptococcus agalactiae in tilapia, Oreochromis niloticus. Fish Shellfish Immunol 2014; 41(2): 250-259.

11. Guide for care and use of laboratory animals. National Academy of Sciences Committee for the Update of the Guide for the Care and Use of Laboratory Animals, the National Academies Press, 8e edition. 2011.

12. Yasmin T, Akter S, Debnath M, Ebihara A, Nakagawa $T$, Nabi $A H$. In silico proposition to predict cluster of $B$ - and $T$-cell epitopes for the usefulness of vaccine design from invasive, virulent and membrane associated proteins of C. jejuni. In Silico Pharmacol 2016; 4(1): 5.

13. Liu $X$, She $X T$, Zhu QF, Li H, Peng XX. Heterogeneous interctome between Litopenaeus vannamei plasma proteins and Vibrio parahaemolyticus outer membrane proteins. Fish Shellfish Immunol 2013; 34(1): 192-198.

14. Devesa R, Moldes A, Diaz-Fierros F, Barral MT. Extraction study of algal pigments in river bed sediments by applying factorial designs. Talanta 2007; 72(4): 15461551.

15. Yang H, Chen H, Jin M, Xie H, He S, Wei JF. Molecular cloning, expression, IgE binding activities and in silico epitope prediction of Per a 9 allergens of the American cockroach. Int J Mol Med 2016; 38(6): 1795-1805.

16. Xi J, Yan H. Epitope mapping and identification of amino acids critical for mouse IgG-binding to linear epitopes on Gly m Bd 28K. Biosci Biotechnol Biochem 2016; 80(10): 1973-1979.

17. Ma $R X$, Cheng LF, Ying $Q K$, Liu RR, Ma TJ, Zhang $X X$, Liu ZY. Screening and identification of an $\mathrm{H}-2 \mathrm{~K}$ Restricted CTL epitope within the glycoprotein of Hantaan virus. Front Cell Infect Microbiol 2016; 6: 151156.

18. Dar H, Zaheer T, Rehman MT, Ali A1, Javed A, Khan GA, Babar MM, Waheed Y. Prediction of promiscuous T-cell epitopes in the Zika virus polyprotein: an in silico approach. Asian Pac J Trop Med 2016; 9(9): 844-850.

19. Tong XL, Guo M, Jin M, Chen H, Li Y, Wei JF. In silico epitope prediction, expression and functional analysis of Per a 10 allergen from the American cockroach. Int J Mo Med 2016; 38(6): 1806-1814.

20. He J, Zhang J, He Y, Huang F, Li J, Chen Q, Chen D, Chen J. Construction of recombinant Mip-FlaA dominant epitope vaccine against Legionella pneumophila and evaluation of the immunogenicity and protective immunity. Immunol Res 2016; 64(1): 272-279.

21. Xu H, Hu C, Gong R, Chen $Y$, Ren N, Xiao G, Xie $Q$, Zhang $M$, Liu Q, Guo A, Chen H. Evaluation of a novel chimeric $B$ cell epitope-based vaccine against mastitis induced by either Streptococcus agalactiae or Staphylococus aureus in mice. Clin Vaccine Immunol 2011; 18(6): 893-900.

22. Corrales-Garcia L, Ortiz E, Castañeda-Delgado J, Bruno Rivas-Santigo. Bacterial expression and antibiotic

Trop J Pharm Res, October 2017; 16(10): 2485 
activities of recombinant variants of human $\beta$-defensins on pathogenic bacteria and M. tuberculosis. Protein Expr Purif 2013; 1:33-43
23. Pokora W, Tukaj Z. Induction time of Fe-SOD synthesis tolerance of two Desmodesmus (greenalgae) strains to chloridazon a study with synchronized cultures. Pestic Biochem Physiol 2013; 107(1):68-77. 